\title{
Methods and Manners of Interpretation of Criminal Norms
}

\author{
Simeneh Kiros Assefa *
}

\begin{abstract}
The criminal justice system is constituted of criminal norms, institutions and methods, among others. Interpretation of the criminal law is a process that transforms the text of the law into reality. The process is influenced by various factors, such as, the courts' conception of the criminal law, the concept and practice of interpretation and how the interpreting institutions understand their role. The understanding of the three elements evolved over the years. The exegetic school, taking statutes as the sole source of the criminal law, argue for using 'strict' methods of interpretation. However, the hermeneutic school holds that interpretation is about the understanding of the law as well as finding the law to the facts of a case, thus, they argue for doctrinal interpretation. The various doctrines of the criminal law constituting meta-norms scaffold the ordinary interpretative methods of the criminal norms. This article discusses the methods in law, which constitute an essential part of the criminal justice system. After a brief introduction of those elements of the 'system', it delves into the structures, the criminal norms as objects of interpretation and their relation to the meta-norms, guiding the interpretation process. It examines the notion of interpretation relative to legislative drafting and augmenting knowledge of the criminal law. Finally, as there are various factors that push the court into the realm of formalism, it also argues for a manner of interpretation, away from judicial formalism.
\end{abstract}

\section{Key terms}

Interpretation, rules, principles, meta-norms, criminal law, object of interpretation, judicial formalism, cassation division

DOI http://dx.doi.org/10.4314/mlr.v11i1.4

This article is licensed under a Creative Commons Attribution-NonCommercialNoDerivs (CC BY-NC-ND)

\footnotetext{
- Simeneh Kiros Assefa , LL.B (Addis Ababa University), LL.M (University of Pretoria), LL.M (Kyushu University), LL.M (University of San Francisco), Assistant Professor of Law at AAU Law School, Attorney-at-Law and member of California State Bar (inactive). Email:<simeneh@simenehlaw.com>
} 


\section{Introduction}

In the past few decades, a different theory of the nature of law has evolved -law is seen as an institution. ${ }^{1}$ This is a middle way between the normative and the realist view of law. A different view of the criminal justice system has also evolved. The legal system is not a system of norms only, as represented by positivists; ${ }^{2}$ rather norms are only one unit in the examination of the legal system; it is the sheer force of the institutions that give life to the dead letters of the law - the formalist school. ${ }^{3}$ These developments appear to have changed the debate on the nature of the law from one of content to a process. Thus, discourse on interpretation of the criminal law should take these new developments into consideration in addition to the theoretical developments in the field of interpretation of law itself.

In order for the law to be applied, it is necessary that the law should be interpreted. It is this conception of interpretation that had taken shape and meaning in past three centuries. This is further assisted by a growing belief that because the courts also define the object of interpretation, they influence the content of the law through interpretation more than the lawmaker does. Sometimes, interpretation is understood as "transformation" of the law. 4 Consequently, because the interpretation process defines the outcome of the case, there are differing opinions on the purpose and method of interpretation.

Interpretation of the criminal law is a 'dialogue' between the judge and the text of the law; this 'dialogue' between the judge and the text of the law is influenced by a host of factors beyond the mechanical methods of interpretation. Defining the scope of the object of interpretation, assumptions on the

${ }^{1}$ O. Weinberger (1991) Law, Institution, and Legal Politics: Fundamental Problems of Legal Theory and Social Philosophy (Dordrecht: Springer); M. La Torre (2010) Law as Institution (Dordrecht: Springer).

${ }^{2}$ H.L.A. Hart (1961) The Concept of Law (London: Oxford University Press). J. Raz (1980) The Concept of a Legal System: An Introduction to the Theory of Legal System, Second Ed. (Oxford: Clarendon Press). H. Kelsen (1970) Pure Theory of Law (Berkley: California University Press) Trans. by Max Knight, represent this view.

${ }^{3}$ R.S. Summers (2006) Form and Function in a Legal System: A General Study (Cambridge: Cambridge University Press). In the introduction, he succinctly discusses the significance of and the credit due to form. In the following chapters, he discusses five areas of functional unites of a legal system and interpretation falls under the methodological type of form. Id., at 54 .

${ }^{4}$ M. Zamboni (2008) Law and Politics: A Dilemma for Contemporary Legal Theory (Berlin: Springer), at 32. L.J. Wintgens (2002) "Rationality in Legislation - Legal Theory as Legisprudence: An Introduction" In L.J. Wintgens (Ed.) Legisprudence: A New Theoretical Approach to Legislation (Oxford: Hart Publishing), at 19. K. Touri (2002) "Legislation between Politics and Law" In L.J. Wintgens (Ed.) Legisprudence: A New Theoretical Approach to Legislation (Oxford: Hart Publishing), at 104. 
organisation of the criminal norms, and the views of the institutions engaged in the interpretation of the law about their interpretative responsibilities most certainly define the outcome of the case.

The Criminal Code expressly prohibits interpretation by analogy; and it contains extensive provisions governing the interpretation and the application of the criminal law. In continental criminal code, the rules are found exclusively in the special part of the code. There are principles predominantly included in the general part; in fact, there are also few principles in the special part. The rules and some principles are the operative part of the criminal law written in "hypothetical-conditional" and consequence manner;" they constitute the criminal norms and are subject to interpretation.

There also are meta-norms, better referred to as 'postulates', such as, the common good principle, the principle of legality, and the non-retroactivity of the criminal law, that regulate and scaffold the interpretation and application of the criminal norm. Often, they are found in the general part of the criminal code, but some, as they are developed in the field of political theory are not fully written in the code. It is within the parameter that is set by those postulates that the ordinary methods of interpretation are applied.

This article examines the normative and institutional elements of interpretation based on the criminal laws, the Federal Supreme Court Sentencing Guideline and the Cassation Division binding interpretative decisions. Section 1 gives a general background of interpretation of law in general and interpretation of the criminal law in particular. Section 2 dwells on how legislative drafting is related to interpretation and how interpretation augments knowledge of the law. It attempts to indicate that the concept of interpretation includes finding the law to the facts of a case and applying such law. It then tries to address issues related to interpretation for better understanding of the notion that interpretation does not stand by itself but is inextricably linked with other areas, such as, drafting of criminal legislation and knowledge of the law.

Section 3 deals with the organisation of the criminal norms and the metanorms. It discusses the meta-norms that 'scaffold' the interpretation of the criminal norms. Section 4 attempts to delimit the scope of the object of interpretation. It argues for hermeneutic interpretation of the criminal law. Section 5 addresses the issue whether and when the criminal law needs to be interpreted. Section 6 deals with the institutions responsible for interpretation, including the Cassation Bench binding interpretative decision making power. Section 7 deals with how interpretation of the criminal law is to be conducted. In this section, the manners of interpretation are discussed. Arguments are

${ }^{5}$ G. Hallevy (2010) A Modern Treatise on the Principle of Legality in Criminal Law (Berlin: Springer), at 16. 
forwarded in this section in favour of substantive interpretation and against formal interpretation with specific focus on the binding interpretative decisions of the Cassation Bench and the sentencing guideline of the Federal Supreme Court as illustrations of judicial formalism.

\section{General Remarks about Interpretation of the Criminal Law}

\subsection{Brief history of the development of the concept of interpretation}

Beyond examination of the various theories of interpretation, the discussion on interpretation of the criminal law involves examination of the content and structure of the criminal norms, the method of interpretation, and the interpreting body's manner of interpretation. There has been a continuous change in those three areas over the centuries having a convoluted effect over the conception and the practice of interpretation of the criminal law.

In the ancien regime, ${ }^{6}$ interpretation was understood by looking at the body that was involved in the practice of interpretation. As there was no separation of power, ${ }^{7}$ every power was vested in the monarch. ${ }^{8}$ Interpretation of the law was, therefore, ultimately vested in the monarch not for his wisdom of interpretation, but rather for the authority he had to make laws. ${ }^{9}$ However, for practical reasons, there were sovereign courts in France, for instance, which were called Parlement. ${ }^{10}$ These courts did not have the power to interpret the law because they were legally prohibited to conduct 'interpretation' of the law in generali, ${ }^{11}$ they just had the power to apply the law. In this period, 'interpretation' was understood to mean deviation from the text of the law, the power exclusively

\footnotetext{
${ }^{6}$ Ancien regime refers to the old regime before the French Revolution.

${ }^{7}$ M. Stolleis (2011) "Judicial Interpretation in Transition from Ancien Regime to Constitutionalism" In Y. Morigiwa, M. Stolleis and J-L. Halperin (Eds.) Interpretation of Law in the Age of Enlightenment: From the Rule of the King to the Rule of Law (Heidelberg: Springer), at 4.

${ }^{8}$ Id., at 6,9 . The judiciary was part of the executive. Id., at 6,13

${ }^{9}$ Id., at 9 .

${ }^{10}$ Parlements were sovereign (higher) courts participating in the legislative process and interpretation of legal texts before the French Revolution. J-L. Halperin (2011) "Legal Interpretation in France under the Reign of Louis XVI: A Review of the Gazette de tribunaux" In M. Stolleis and J-L. Halperin (eds.) Interpretation of Law in the Age of Enlightenment: From the Rule of the King to the Rule of Law (Heidelberg: Springer), at 22, 36. L.B. Register (1916) "Judicial Power of Interpretation under Foreign Codes" In 65 U. of Penn. L. Rev. and Am. L. Register No 3, at 40.

${ }^{11}$ Halperin, supra note 10, at 23.
} 
vested in the Monarch. ${ }^{12}$ That is why there had been serious objection to interpretation of the law by the courts. ${ }^{13}$

The French developed a wise distinction between authoritative (authentic) interpretation which was vested in the monarch and doctrinal interpretation vested in the courts. ${ }^{14}$ Such distinction was necessary because of the plurality of laws that were applicable; i.e., there were laws potentially applicable to a particular case, such as, ecclesiastical law, Roman law, French law, and customary law. ${ }^{15}$ In this doctrinal interpretation, the courts determined which law is applicable, the knowledge (and skill) that was very much lacking in the monarch, and they decided the content of such law. ${ }^{16}$

The judgments of the courts were very shorthand, only a page or two, and the methods of interpretation of the law were vague. ${ }^{17}$ Those judgments include only the name of the parties, the summary of the facts, and the finding of the court; there was no reason provided for the conclusion. ${ }^{18}$ Those judgements were published in publication called Law Reports. ${ }^{19}$ The reason for publication

${ }^{12}$ E. Freund (1917) "Interpretation of Statutes" In 65 U. of Penn. L. Rev. and Am. L.

Register No 3, at 208.

${ }^{13}$ For instance, it is this aspect that Voltaire refers to as "corruption" of the law. Halperin, supra note 10 , at 29 . He is also quoted for asserting that judicial interpretation is "the most detestable of all institutions." Freund, supra note 12, at 208. As such, there were efforts to avoid judicial interpretation. For instance, Napoleon drafted a code with a commentary that would exclude interpretation; the Austrian law had included 19,000 sections in order to make the law as clear as possible. All such efforts were, however, unsuccessful. R. Zimmermann (1997) "Statutas unt strict einterpretanda? Statutes and the Common Law: A Continental Perspective" In 56 The Cambridge L. J., No 2, at 325, 326. H. Mohnhaupt (2011) "The Object of Interpretation: Legislation and Competing Normative Sources of Law in Europe During the $16^{\text {th }}$ to $18^{\text {th }}$ Centuries" In M. Stolleis and J-L. Halperin, (eds.) Interpretation of Law in the Age of Enlightenment: From the Rule of the King to the Rule of Law (Heidelberg: Springer), at 88. Y. Morigiwa (2011) "Interpretation by Another Name: The Function of Rechtsfindung in the Modern State" In Y. Morigiwa, M. Stolleis, and J-L. Halperin (Eds.) Interpretation of Law in the Age of Enlightenment: From the Rule of the King to the Rule of Law (Heidelberg: Springer), at 134.

${ }^{14}$ Halperin, supra note 10 , at 24.

${ }^{15}$ Id., at $24,25$.

${ }^{16}$ Id. S. Dauchy (2011) "Legal Interpretation and the Use of Legal Literature in the $18^{\text {th }}$ Century Law Reports of the "Parlement" de Flandre" In Y. Morigiwa, M. Stolleis, and JL. Halperin (Eds.) Interpretation of Law in the Age of Enlightenment: From the Rule of the King to the Rule of Law (Heidelberg: Springer), at 54.

${ }^{17}$ Generally, see Dauchy, supra note 16.

${ }^{18}$ Id., at $48,55$.

${ }^{19}$ These Law Reports were published by those who were "insiders", such as, judges and state advocates taken from their personal notes and notes meant to be for office use. 
of those Law Reports was to provide material to lawyers and judges from which to abstract a general principle of interpretation of the law. ${ }^{20}$

As these judgments published in the Law Reports were not binding as precedents, they died out, and were progressively substituted by dictionaries. Those dictionaries were meant to be coherent and comprehensive writings on a given subject. ${ }^{21}$ These dictionaries helped the development of legal doctrines or principles. $^{22}$

From the publications of those dictionaries, two developments followed: first, as those doctrines helped to systematically organize rules, they facilitated the codification of the law. ${ }^{23}$ Second, later developments took advantage of the French distinction between authoritative and doctrinal interpretation, ${ }^{24}$ and because the codes required substantial knowledge of the law, freedom of interpretation of the law by the court evolved. ${ }^{25}$ However, in order to limit the power of the court deviating from the text of the law under the guise of interpretation, the codes were accompanied with commentaries. ${ }^{26}$ In several areas of the law, the decision of the cassation court had been found to be a useful tool in guiding the lower courts in the interpretation of the law. ${ }^{27}$

\subsection{The change in the notion of the nature of the law}

Interpretation is also impacted by the change in the conception of the law. The Age of Enlightenment is known for the positivisation of laws in general and the criminal law in particular. Thus, the progressive positivisation of the law requires specific rules of interpretation ${ }^{28}$ having such a statute as its object. ${ }^{29}$

${ }^{20}$ Halperin, supra note 10 , at 22. Dauchy, supra note 16 , at 50.

${ }^{21}$ Unlike the Law Reports, which were published by 'insiders', those dictionaries were published by those who were 'outsiders' of the realm of the practice of law. Halperin, supra note 10, at 30,31. Dauchy, supra note 16, at 56 .

${ }^{22}$ Dauchy, supra note 16 , at 56, 49 note 14 .

${ }^{23}$ Id., at 57. Mohnhaupt, supra note 13 , at 88.

${ }^{24}$ Halperin, supra note 10, at 43. Dauchy, supra note 16 , at 57

${ }^{25}$ Halperin, supra note 10, at 24, 36, 43. Stolleis, supra note 7, at 14. J. Schroder (2011) "The Concept and Means of Legal Interpretation in the $18^{\text {th }}$ Century" In Y. Morigiwa, M. Stolleis, and J-L. Halperin (Eds.) Interpretation of Law in the Age of Enlightenment: From the Rule of the King to the Rule of Law (Heidelberg: Springer), at 93.

${ }^{26}$ Mohnhaupt, supra note 13, at 88 .

${ }^{27}$ Halperin, supra note 10, at 22, note 2; at 43; Freund, supra note 12, at 209.

${ }^{28}$ As the positivisation of the law had been evolving substituting the natural law, there were two fundamental principles of interpretation developed from the Roman law; i.e., 1. the latter prevails over the former and 2. the special prevails over the general. However, there had also been one fundamental rule that was a part of the Roman law but given significant place subsequent to the French Revolution: judges could not avoid making decisions based on absence of law; therefore, they had to decide by analogy. In this period, there had not been difference in rules of interpretation in criminal matters and other matters. 
This brought about some level of idolatry of statutes $;^{30}$ the early $17^{\text {th }}$ century French exegetic school believed that the only source of law is statute. ${ }^{31}$ It disregarded the theoretical conception as well as doctrinal interpretation and analysis of the law. ${ }^{32}$ The concept of law is different depending on who is arguing for that notion, such as, a positivist, a naturalist, a realist, etc.; there was, however, a general consensus that the criminal law has to be written having a general part and a special part. The general part is all about doctrines.

\subsection{Fundamental structure of continental criminal law}

The contemporary continental criminal law has four basic foundational principles; the principle of legality, the principle of conduct, the principle of culpability and the principle of personal responsibility. ${ }^{33}$ The foundation of all these four principles is the individual free will which are also referred to as "supra-principle". ${ }^{34}$ The purpose of criminal law is maintaining the social existence of men by preventing crime. The actions of members of such society of men which is a threat or harm to such social existence is proscribed if it is the result of choice made exercising the free will of the individual.

From these four fundamental principles, four major substantive and structural outcomes follow. First, from the principle of legality follows that there is a crime and a consequent measure or punishment only that is provided for in the law. The law must specifically and clearly state the prohibited conduct and the consequent measures. This further restricts the creation of crimes and punishment by analogy. Second, from the principle of conduct, it follows that a person can be held liable for a crime that is possible for commission and such conduct must be a positive conduct provided for in the law as proscribed. ${ }^{35}$ Third, from the principle of culpability, it follows that a person may be held liable if he acted with a criminal guilt; i.e., the individual is criminally

However, in the humanist movement, a distinction between interpretation of the civil law and interpretation of the criminal law was made based on criminal law doctrines rather than rules of interpretation. Zimmermann, supra note 13, at 316, 316.

${ }^{29}$ Mohnhaupt, supra note 13 , at 62.

${ }^{30}$ Halperin, supra note 10 , at 38 .

${ }^{31}$ Dauchy, supra note 16, at 45. M. Troper (2011) "What Is Interpretation of Law for the French Judge?" In Y. Morigiwa, M. Stolleis and J-L. Halperin (eds.) Interpretation of Law in the Age of Enlightenment: From the Rule of the King to the Rule of Law (Heidelberg: Springer), at 139, 144. The restriction on the scope of interpretation until the middle of the $20^{\text {th }}$ century is elaborated by J. Bonnecase (1930) "The Problem of Legal Interpretation in France" 12 J. Of Comp. Legislation and Int. L., No 1.

${ }^{32}$ Dauchy, supra note 16 , at $45,46$.

${ }^{33}$ Hallevy, supra note 5 , at $3-5$.

${ }^{34}$ Ibid.

35 Exceptionally, the failure to act is also punished but the inaction must be a positive abandoning in order to bring about a certain result or in a breach of duty. 
responsible for her intentional act, and in exceptional circumstances when it is expressly provided for, for her negligent conduct. Accidents (actions without guilt) are not criminal conducts. She is responsible for what she intends as a consequence; she is not responsible for anything that exceeds her desired consequence. Likewise, she is not responsible for consequences that went beyond her duty of care. Fourth, from the principle of personal responsibility, it follows that the individual is responsible for her own guilty action only; there is no vicarious criminal responsibility.

These four core principles of continental criminal law are incorporated into the Ethiopian Criminal Code. The principle of legality is provided for under Art 2 ; the material objects of crime, including degrees of commission of a crime and of participation, are provided for under Arts 23-47; subjective elements of crime are provided for under Arts 57-67, and Arts 48-56 which provide for the mental responsibility; further, justificatory defences and excuses are provided for under Arts 68-80. Finally, personal responsibility of the individual is provided for under Art 41.

\section{Interpretation, Legislative Drafting, and Augmenting Knowledge of the Criminal Law}

In addition to the foregoing general discussion regarding the nature of interpretation, we need a clear definition and discussion on the scope and practice of interpretation of the criminal law. Currently, interpretation may be understood to be a judicial activity in an effort to finding the law applicable to the facts of the case in dispute, giving content to the provision of the law and applying such law to the disputed facts. ${ }^{36}$

Interpretation has evolved to the level it has today for two reasons; first, the criminal law is now primarily positive law from which (adverse) deviation renders the law invalid; ${ }^{37}$ and second, the judiciary has developed as an independent institution to interpret the criminal law. However, the understanding

\footnotetext{
${ }^{36}$ Smith opines interpretation is a matter of fact because he believes it is a judicial activity in applying a rule to a certain fact. H.A. Smith (1927) "Interpretation in English and Continental Law" In 9 J. of Comp. Legislation and Int. L., No 4, at 153. However, others hold it is a matter of law because the content of the law is determined by the rules of interpretation. Freund, supra note 12, at 207. H. Silving (1950) "A Plea for a Law of Interpretation" In 98 U. of Penn. L. Rev., No 4, at 503. Whether interpretation is a matter of law or a matter of fact, the above argument is only based on their subsequent points and they did not critically examine the facts or the concept of interpretation itself. Those who argue interpretation is a matter of law subsequently discuss about rules of interpretation.

37 A. Ornowska (2010) "Introducing Hermeneutic Methods in Criminal Law Interpretation in Europe" In J. Jemielniak, P. Miklaszewicz (Eds.) Interpretation of Law in the Global World: From Particularism to a Universal Approach (Heidelberg: Springer), at 252.
} 
of the concept and practice of interpretation have become much more complex and sophisticated because it is seen in different contexts, including lawmaking and human communication.

\subsection{Legislative drafting and interpretation of the criminal law}

Often, it is indicated that legislative drafting and interpretation of the law are 'inextricably' connected ${ }^{38}$ and that drafting guides interpretation. ${ }^{39}$ This is because the lawmaker and the body interpreting the law (i.e., the court) are different bodies, and the law is a communication between them. However, in order to make the communication of the intention of the lawmaker clear, the law is drafted by professionals following certain rules governing such conduct. ${ }^{40} \mathrm{In}$ not few cases, the legislature also defines certain commanding terms in the law. ${ }^{41}$ In the criminal law, the general part is meant to do just that.

The criminal law has two purposes ${ }^{42}$ - as a rule of conduct, it gives notice to the ordinary citizen to conform his conduct to the requirements of the law; thus, the principle of legality requires clarity in the statement of the law. The criminal law, as a rule of adjudication, on the other hand, is directed to the professionals; thus, for simplicity reason, it uses certain terms of art which have several preconceptions and intricacies. ${ }^{43}$

These apparently conflicting interests negatively impact the drafting of the criminal law as each purpose is pulling the drafters in opposite direction in the selection and use of words. Often the rules of adjudication hide the rules of conduct for drafters focus on the former. ${ }^{44}$ Certainly, the general part of the criminal law is drafted in a manner an ordinary person may not understand. However, the special part of the criminal law is clear more often than not. The Special Part of the Criminal Code focuses on the rules of conduct while the General Part deals with general rules applicable to all offences including rules of

${ }^{38}$ Zimmermann, supra note 13 , at 325 .

${ }^{39}$ Graven reflects on his concern on the application of the law when he drafted the 1957 Penal Code. Thus, he endeavoured to make the Code "as clear, complete and precise as possible" both to the judge and the ordinary citizen. J. Graven (1964) "The Penal Code of the Empire of Ethiopia" In 1 J. Eth. L No 2, at 281, 287. Freund, supra note 12, at 216.

${ }^{40}$ Smith, supra note 36 , at 155 . Wintgens, supra note 4 , at $15,16$.

${ }^{41}$ Often in various proclamations the legislature defines words and phrases which are frequently used in such legislation or which are key to the interpretation and application of such legislation. Yet, even those defined words are subject to judicial interpretation.

${ }^{42}$ P.H. Robinson (2000) "Structuring Criminal Codes to Perform Their Function" In 4 Buff. Crim. L. Rev., No 1, at 1-5.

${ }^{43}$ Silving, supra note 36 , at $514,515$.

${ }^{44}$ Id., at 5, 6. The general observation is that, in his reflections, Graven, again, was very much concerned about how the judge could find the law, in the new Code, to a particular case. Graven, supra note 39, at 281-283. 
adjudication; but their areas of focus are not mutually exclusive. ${ }^{45}$ Thus, in drafting the criminal law, the lawmaker needs to have these purposes in mind for a proper communication to both the citizen (so that the law can be complied with), and to the court so that the intention of the lawmaker may properly be enforced in the event the law is violated. ${ }^{46}$

\subsection{Interpretation of and augmenting knowledge of the law}

There are different understandings regarding knowledge of the law and interpretation of the law. Some opine that interpretation of the law presupposes knowledge of the law; ${ }^{47}$ while others believe that interpretation facilitates comprehension of the law. ${ }^{48}$ The conclusions of these discussions depend of the content of their argument. Often interpretation comes to the fore in the adjudication process. In this case, the body interpreting the law has to be able to establish both the facts of the case and the applicable rules. ${ }^{49}$ Morigiwa states that "finding the facts of a case" is an essential skill for a lawyer as well as interpretation of the law. ${ }^{50}$ For him what is called 'interpretation' is finding the law applicable to a given case. ${ }^{51}$ His conclusion is founded on knowledge defined to be "the grasp of truth" ${ }^{52}$ For knowledge of a particular object, he argued, we need to have the three terms -(we) the knowing subject, the subject to be known (the object), and the communication of such knowledge to others. ${ }^{53}$ Interpretation of the law, he argues, is in perfect fit to this three-term analysis of knowledge. ${ }^{54}$ The facts and the applicable rules are the objects.

However, what makes judicial interpretation different from the interpretation made by the parties is that, the court has monopoly of 'truth'. ${ }^{55}$ The court has the

${ }^{45}$ Hallevy, supra note 5, at 145.

${ }^{46}$ Crim. C., Art 1, paras 1 and 2 respectively.

${ }^{47}$ Zimmermann, supra n 13, at 319. 323. Endicott generally argues that interpretation is an activity, an activity outside of our mind, while comprehension is passive and it is in our mind. Thus, the two are different. T.A.O. Endicott (1994) "Putting Interpretation in Its Place" In 13 Law and Philosophy, No 4.

${ }^{48}$ Silving, supra note 36 , at 511, 518, 519 .

${ }^{49}$ Morigiwa, supra note 13 , at $126,133$.

${ }^{50}$ Id., at 133 .

${ }^{51}$ Id., at 126, 133. The art of finding the facts of a case and interpretation of the law applicable to that case, in German, is called Rechtsfindndung. Id., at 133. Morigiwa refers to this as another name of interpretation. Id., at 137.

${ }^{52}$ Id., at 132.

${ }^{53}$ Id., at 127-131. According to Morigiwa, "the knowing subject and the subject to be known are transcendent to each other." What has to be addressed is communication which is corresponding the proposition in our mind which we believe to be true with that of the state of affairs outside our mind - in this case the facts of the case and the rule. Id., at 128.

${ }^{54} \mathrm{Id}$., at 131

${ }^{55}$ Id., at 126, 133. Ornowska, supra note 37, at 268, 269. 
authority to declare the outcome of the case and the interpretative question. Truth, in this sense, means determination of the interpretative question, the methods of interpretation, the facts that are deemed proved, and the applicable rules. ${ }^{56}$ It is this truth that controls the process of interpretation; interpretation in this sense "brings about authority and stability" of the law, ${ }^{57}$ because it is when the law is applied that it enters the social consciousness as the law is a social edifice. $^{58}$

\section{Organisation of Criminal Norms}

Interpretation applies to criminal norms in general which may include rules or principles provided for in the criminal law. Their interpretation is facilitated by meta-norms called postulates.

\subsection{Rules}

In the level of abstraction, rules are lower level norms. They are stated in clear manner than principles, providing for in general terms but less abstract. Generally, rules have certain qualities that are unique to them -they are drafted in a 'hypothetical-condition' and consequence manner. ${ }^{59}$ The condition contains the operative facts, such as, the material and moral elements that are proscribed. Once the conditions are met, i.e., the crime is committed, the consequence, i.e., the measure or punishment, automatically follows. ${ }^{60}$

The criminal law rules are meant for regulation of conduct. As such, they are required to meet certain formal and substantive requirements to perform their function efficaciously. ${ }^{61}$ Rules have to be "prescriptive" and "complete" in their

\footnotetext{
${ }^{56}$ Morigiwa, supra n 13, at 133.

${ }^{57}$ Id., at 134 .

${ }^{58}$ Mohnhaupt, supra note 13, at 61.W.S. Landecker (1941) "Criminology in Germany" In $31 \mathrm{~J}$. of Crim. L. and Criminology, No 5, at 553. Prott states that judgement "reconcile[s] an audience with the use of power" which is "insulated" from administrative type control. Such reconciliation is made by way of relating the case at hand with the existing established legal tradition. L.V. Prott (1978) "Judicial Reasoning in the Common Law and Code Law Systems" In 64 Archives of Philosophy of Law and Social Philosophy No 3, at $418,419$.

${ }^{59}$ Hallevy, supra note 5, at 12.

${ }^{60}$ H. Avila (2007) Theory of Legal Principles (Dordrechet: Springer), at 11, 12, 29.

${ }^{61}$ Summers does not appear to be clear in his statements whether he is referring to rules in general or to rules as opposed to principles. However, in discussing this requirement he is focusing exclusively on "statutory rules" and rules as opposed to principles and maxims. Summers, supra note 3, at 136, 137.
} 
form and content ${ }^{62}$ "general" in their statement, ${ }^{63}$ "definite" in their application, have a "good internal structure" and be formal and simple in their manner of expression. ${ }^{64}$ Where the rules appear to be incomplete, based on the principle of complementarity of rules, the General Part of the Criminal Code complements the apparent gap in those rules. ${ }^{65}$ The issue may be whether, in view of the principle of legality and strict interpretation of the criminal law, we can go beyond the text of the Code for finding the rules. In finding the rules, we cannot go beyond the express provisions of the law. However, it is evident that both the hypothetical conditions and the consequences need interpretation.

For instance, in Ali, et. al. ${ }^{66}$ defendants were charged for violation of the provisions of Art 4 of Anti-Terrorism Proclamation No 952/2009. ${ }^{67}$ The Court did not find it easy to abstract the content from the reading of those provisions nor could they be supplemented by the principles in the General Part of the Criminal Code; it thus went to the travaux préparatoires to establish the content of those provisions because the provisions were vague or 'incomplete' to use the words of Summers. ${ }^{68}$ In such cases, the court should have ignored the rule as it defeats the purpose the criminal law as a rule of conduct.

${ }^{62}$ Summers argues that a rule is complete if it addresses matters of "(1) scope, (2) addressees, (3) requiring mental state of actors, (5) circumstances of acting, and (6) effects of action." Id., at 147.

${ }^{63}$ The generality of the law is required for two reasons. First, it is committed to the principle of equality when there is "one law for all" without having anyone in mind; second, the "general formulation" of the criminal law requires development of a policy on which it is based. Hallevy, supra note 5, at 135.

${ }^{64}$ See, Summers, in general, supra note 3, Chapter 5.

${ }^{65}$ Hallevy, supra note 5, at 145; Summers, supra n 3, at 147.

${ }^{66}$ Public Prosecutor v. Ali Aduros, et. al. (11 December 2014, Federal High Court, File No 134044)

${ }^{67}$ Art 4 provides that "Whoever plans, prepares, conspires, incites or attempts to commit any of the terrorist acts stipulated under sub-articles (1) to (6) of Article 3 of this Proclamation is punishable in accordance with the penalty provided for under the same Article." This necessarily requires the reading of article 3 of the Proclamation which provides that: "Whosoever or a group intending to advance a political, religious or ideological cause by coercing the government, intimidating the public or section of the public, or destabilising or destroying the fundamental political, constitutional or, economic or social institutions of the country: (1) causes a person's death or serious bodily injury; (2) creates a serious risk to the safety or health of the public or section of the public; (3) commits kidnapping or hostage taking; (4) causes serious damage to property; (5) causes damage to natural resources, environment, historical or cultural heritages; (6) endangers, seizes or puts under control, causes serous interference or disruption or any public service..."

${ }^{68}$ Ali, supra note 66. 


\subsection{Principles}

The General Part of the Criminal Code contains the principles of the criminal law. There are also few principles scattered in the Special Part of the Criminal Code that guide the specific rules. There is a higher level of abstraction in these principles, and they serve both as the pool for rules in drafting, and for understanding of those rules in interpretation. The principles often help in the correct interpretation of the law because they set the foundation for rules.

The relationship between the rules and principles makes it difficult to make a proper distinction between the two as they 'tend to blend'. ${ }^{69}$ With some reservation, Avila makes a distinction between rules and principles based on four grounds: i.e., content, mode of application, normative relations and axiological foundation. ${ }^{70}$ Regarding their content, rules are "hypotheticalconditional" -consequential; ${ }^{71}$ as such, when the conditions are met, the consequences follow. On the other hand, principles only give guidance to the judge regarding final findings. ${ }^{72}$ Although this is a unique character of rules, it is not exclusive to them; rarely, principles also have this quality. ${ }^{73}$

Rules are applied as "all or nothing" in terms of mode of application. ${ }^{74}$ This may also be seen in their relations to each other. Thus, if there is a conflict between two rules, only one of them is applied rendering the other ineffective, unless the latter is considered as an exception of the other. ${ }^{75}$ The application of principles, on the other hand, is in degrees, as they have relative weight. ${ }^{76}$ This is also seen in the context of conflict between principles; when two principles collide, "the principle with higher relative weight superpose without invalidating the other". ${ }^{77}$ The collision of rules is manifested in the invalidation of one of the rules while the conflict between principles is manifested in their application. ${ }^{78}$

${ }^{69}$ Avila, supra note 60 , at 17.

${ }^{70}$ Id., at $11,12$.

${ }^{71}$ Id., at 11 .

${ }^{72}$ Id., at $11,12$.

${ }^{73}$ For instance, as homicides are of different type and degree, the "principle" put under Art 538 provide for the basic conditions to be met in any type of homicide case. Thus, Crim. C., Art 538(1) provides that "Whoever causes the death of a human being intentionally or by negligence, no matter what the weapon or means used, commits homicide." The rest of the provisions provide for specific conduct so that such act would fall under, such as, "Aggravated Homicide", or "Ordinary Homicide" or "Extenuated Homicide." Graven, supra note 39 , at 282.

${ }^{74}$ Avila, supra note 60 , at 11,14 .

${ }^{75}$ Id., at $19-21$.

${ }^{76}$ Id., at 19.

${ }^{77}$ Id., at 11, 19.

${ }^{78}$ Id., at 20 . 
The nature of rules and principles varies, inter alia, in their level of abstraction principles are much more abstract than rules, which are very specific. ${ }^{79}$

\subsection{Meta-norms or postulates of the criminal law}

Rules and principles are discussed as rules of conduct or adjudication; they are norms of the criminal law subject to interpretation and application to specific fact situation. Meta-norms are not norms; they are about norms. Thus, norms and meta-norms are not on the same level. Norms are subject to interpretation and application while meta-norms are about how these norms are to be interpreted. ${ }^{80}$ The criminal law rules and principles, as rules of conduct, are directed to the citizen and they are (as rules of adjudication) directed to the public power; while meta-norms, on the other hand, are directed to the interpreter of the criminal norm. ${ }^{81}$ The last distinction between norms and metanorms is that, norms influence each other either by complementing each other or by contradiction. For instance, when two rules collide, one of them is validated while the other is invalidated, unless it is declared an exception. Likewise, when two principles collide, "the principle with a higher relative weight superposes without invalidating the other". ${ }^{82}$ Meta-norms, on the other hand, set the guideline regarding the interpretation and application of those rules and principles without conflicting each other. ${ }^{83}$

Those meta-norms are classified into two categories. The first category relates to hermeneutic postulates that help the comprehension of norms and the legal order. ${ }^{84}$ The single most important hermeneutic postulate is the postulate of unity of legal order; postulate of coherence is the sub-element of postulate of unity of legal order. ${ }^{85}$ The second category is applicative postulate, as it is related to the application of norms. These are further classified into non-specific postulates, ${ }^{86}$ such as, legal goods, practical accordance and prohibition of excess, and specific postulates, such as, equality, ${ }^{87}$ proportionality and

\footnotetext{
${ }^{79}$ Id., at $17,94$.

${ }^{80} \mathrm{Id}$., at 83.

${ }^{81}$ Id., at 83 .

${ }^{82}$ Id., at $11,19$.

${ }^{83} \mathrm{Id}$., at 83 .

${ }^{84}$ Id., at 84.

${ }^{85}$ As can be abstracted from the provisions of Arts 3, 432-34 of the Criminal Code, the criminal lawis considered as one body of law, including any possible criminal rule contained in the Criminal Code or any other separate legislation, such as, special criminal legislation or penal provisions contained administrative legislation. Graven, supra note 39 , at 282, 284, 285, 287.

${ }^{86}$ Avila, supra note 60 , at $99-104$.

${ }^{87}$ Avila illustrated that equality is used, uniquely, as a rule, as a principle and as a postulate in different circumstances. Id., at 104.
} 
reasonableness. ${ }^{88}$ The following postulates of criminal law can properly be classified accordingly as some of them relate to the application of the criminal law while others may fall under hermeneutic category as they relate to the comprehension of rules and principles of the Special Part. Once we set the distinction between those norms and meta-norms, we shall specifically discuss the majority of the meta-norms many of which are provided for in the General Part of the Criminal Code while few of them are not.

\subsubsection{The protection of the common good purpose of the criminal law}

The criminal law is used for achieving certain ends. ${ }^{89}$ The protection of those ends is a value preference involving weighing of various interests, which appears subjective preference, but with objective criterion: the common good of the human society. ${ }^{90}$ The common good is, thus, the umbrella doctrine of the criminal law that defines the purpose and function of the criminal law; i.e., it evaluates whether the state has used the criminal law for legitimate purposes or not, taking the scope of criminal law out of the whims of the lawmaker which is least invoked doctrine in the judicial process. ${ }^{91}$ The doctrine of the common good limits the state's use of coercive power as a last resort measure because it both positively states the scope of the criminal law and normatively dictates the lawmaker as to what conducts to criminalise. ${ }^{92}$

${ }^{88}$ Id., at 104-123. Those postulates are formal in the sense that they do not have specific content; they rather depend on circumstances. For instance, in the postulate of equality, there have to be two circumstances to put under comparison without which equality remains an empty container. Id., at 98.

${ }^{89}$ B.Z. Tamanaha (2006) The Law as a Means to an End: Threat to the Rule of Law (Cambridge: Cambridge University) at 69, 190.

90 Id., at 23,75 . It is the principle of utility that changed this subjective issue, a moral question, into empirical science. There are efforts to make the value preferences based on objective standards. Avila, supra note 60, at 99, 100.

${ }^{91}$ Avila states that "legal good" is a non-specific postulate that is used to weigh all possible interests. Weighing without subjective and objective criteria is of very little use. However, the weighing of interests is much broader postulate than specific postulates, such as, proportionality, equality or reasonableness, postulates very much useful in the evaluation of punishment than criminalization. Id., at 99.

${ }^{92}$ For in-depth reading on the concept of the "common good" or "protected legal interest", generally see Simeneh Kiros Assefa and Cherinet WordofaWetere (2018) "OverCriminalisation": A Review of the Special Penal Legislation and Penal Provisions" In 28 J. Eth. L No 2 (forthcoming). S. Mir Puig (2008) In "Legal Goods Protected by the Law and Legal Goods Protected by the Criminal Law, as Limits to the State's Power to Criminalize Conduct" In 11 New Crim. L. Rev.: An International and Interdisciplinary Journal, No 3.M.D.Dubber (2005) "Theories of Crime and Punishment in German Criminal Law"In 53 Am. J. of Comp. L., No 3.L.E. Chiesa (2008) "The Rise of Spanish and Latin American Criminal Theory" In 11 New Crim. L. Rev., No 3. N. Persak (2007) 
This doctrine is partly a rule of validation for criminal norms. Thus, it is helpful in the interpretation of the criminal law for two reasons. As a rule of validation, criminal norms that are not compatible with this doctrine are not valid, hence, not applicable. They are not valid, either because the interest they protect is not a substantial interest not in need of criminal law protection ${ }^{93}$ or the interest can effectively be protected by other means, such as, administrative actions and civil remedies. ${ }^{94}$

The state regulates almost all aspects of life in society. Unwise use of criminalization becomes more damaging to the public than the unregulated conduct of the individual. For example, Art 433 of the Ethiopian Criminal Code has a general criminalisation stipulation on conducting business without license, where one is required. There is a regulation of banking business, waste disposal, doing a professional work, broadcasting, etc., each of which are criminally sanctioned under the respective legislation. However, trading without a license can effectively be regulated by administrative measures and civil actions than by the criminal law unless (a) the area of trade is a professional work that requires special expertise, such as, medical service, legal service, and accountancy, without which significant damage may be caused to those who sought the service; or (b) the area is strictly regulated in order to protect the social order, such as business undertakings in banking, insurance, and waste disposal.

However, courts focus on the application of the law than on interrogating it in light of the common good. For instance, the Federal Supreme Court Cassation Bench in Daniel (section 3.3.2.A infra.) considered objectives of other administrative proclamations for guidance to interpret the penal provisions contained therein rather than the doctrine of the common good. This is probably because the determination of validity of the law based on the concept of protected legal interest or the common good requires the judge to go beyond the text of the law, ${ }^{95}$ which the court may find difficult for various reasons.

Criminalising Harmful Conduct: The Harm Principle, Its Limits and Continental Counterparts (New York: Springer), Chapter III.

93 Mir Puig, supra note 92, at 411, 412. Simeneh and Cherinet, supra note 92, section 2.3. F. Molina (2011) "A Comparison Between Continental European and Anglo-American Approaches to Overcriminalization and Some Remarks on How to Deal with It" In 14 New Crim. L. Rev. No 1, 124. D. Husak (2004) "The Criminal Law as Last Resort” In 24 Oxford J. of Legal Studies No 2, at $208 \mathrm{ff}$.

94 Simeneh and Cherinet, supra note 92. Mir Puig, supra note 92, at 418. Husak, supra note 93, at $208 \mathrm{ff}$.

95 Despite some reservations, the concept of "common good" is used to test the legitimacy of the criminal law. Wintgens, argues that "thinking in terms of rules is still the dominant pattern of legal thinking" and he attempts to question the legitimacy of law and false consciousness of rule of law from an external point of view; supra note 4, at 14. Thus, the legitimacy cannot be questioned from inside; the legitimacy can effectively be 


\subsubsection{The principle of legality}

The principle of legality is a fundamental principle in any modern criminal law. In the Ethiopian criminal law, the principle of legality has five sub-principles the power to declare the law and the manner of declaration of such norms, temporal and spatial application of those norms, interpretation of such criminal norms, and prohibition of double jeopardy.

\section{A. The power to declare and the manner of declaration of the criminal norm}

The criminal law rules are conditional statements, i.e., a criminal law rule has both a condition clause, the operative facts that constitute the crime, and a consequence clause which is the measure or punishment attached to the condition when fulfilled. Those conditions must be valid; i.e., the conditional clause must refer to "actual occurrences that could happen or occur". ${ }^{96}$

Both the conditions and their consequence must be published in the official gazette, such as, the Federal Negarit Gazeta, ${ }^{97}$ and that there is no crime or punishment other than what is provided for in the law. ${ }^{98}$ This publication is required for two major reasons. First, it is fair to the individual to give him notice of what is prohibited and what is required of him so that he would foresee the consequences and be able to conform his conduct to the requirement of the

examined from outside. Persak, supra note 92, at 110. Dubber, supra note 92, at 685, 691,92 . When the questioning of the legitimacy of the criminal law goes beyond the rules it goes to the realm of politics. Thus, Zamboni discusses three models of the relationship between law and politics -the first model is the autonomous model represented by the positivists in which the law is treated independently of politics, the second is the embedded model in which politics is embedded in the law represented by, such as, the critical studies, and the third is the intersection model which is represented by the realist school which argues for the intersection of law and politics. His study is examining the static aspect, looking at the law and politics, the dynamic aspect, i.e., looking at the law making process and the political order, and third the epistemological aspect looking at the legal discipline and the political material. Zamboni, supra $n 4$.

96 Hallevy, supra note 5, at 16 . Such is the case with impossible crime where the condition is invalid.

97 A Proclamation to Provide for the Establishment of Federal Negarit Gazeta, Proclamation No 3/1995

98 This is expressly provided for under Crim. C., Art 2(1). Interpretation by analogy was a proper method in the Fiteha Negest; the ninth condition in order for one to become a judge is to know the law and being "able to draw analogies." Fiteha Negest: The Law of the Kings (Trans. Abba Paulos Tsadwa in 1968), (Addis Ababa: Law Faculty, HSIU), at 251. As the punishments for specific offences were provided for in the 1930 Penal Code, it could be argued that the analogical interpretation is only for elements constituting the crime. However, if the elements of the crime were to be interpreted by analogy, necessarily the punishments had the same fate. Graven, supra note 39, at 273-76. 
law. ${ }^{99}$ This would give him a chance to plan his life; it would certainly be unfair to try him on the basis of a law that is not declared nor exist at the time of the alleged conduct because it could not be complied with anyway. Once the law is published, the individual is assumed to have known the content of the law, and ignorance of law is no excuse. ${ }^{100}$

Second, the purpose of the criminal law is prevention of crime by giving due notice of the proscribed conduct and the consequent measures or punishments so that the individual would comply with the rules of conduct in society. It is generally believed that the individual would comply. Therefore, publication of the criminal law is an efficient way of enforcement of the criminal law. ${ }^{101}$ An essential part of this sub-principle (which is intimately connected to publication of laws) is the authority to declare the criminal law.

According to Art 55(5) of the FDRE Constitution, The federal lawmaking body is the House of Peoples' Representatives, and in effect, all elements that constitute a crime and the consequent measures and punishments have to be defined by this body having the power to declare the criminal law. This power cannot be delegated to the Council of Ministers or any Government Agency. ${ }^{102}$ However, several administrative proclamations authorise the Council of Ministers to adopt Regulations; the Regulations in turn authorise the particular Agency to adopt directives. Regulations and Directives often provide for the operative facts. Those various proclamations routinely provide that violation of the Proclamation, the Regulations and Directives issued under such Proclamation is punishable. ${ }^{103}$ Sometimes a specific penal measure is stated in some

99 Hallevy, supra note 5, at 26, 36. Ornowska, supra note 37, at 253.

${ }^{100}$ Crim. C., Art 81(1).

${ }^{101}$ Hallevy, supra note 5, at 26. Ornowska, supra note 37 , at 253 . This obviously is an instrumentalist aspect of the criminal law. Tamanaha, supra note 89 , at 71 . In the hierarchy of lawsthere is the Constitution at the top followed by proclamations and Regulations, adopted by different entities, published in the Negarit Gazeta. There are also directives, adopted by specific agencies, which have never been published in the Negarit Gazeta. Even though they often contain operative part of the criminal norm, they are not effective measures for notice. Thus, they cannot in any way negate the defence of ignorance of law. Cim. C., Art 81(3).

${ }^{102}$ Simeneh and Cherinet, supra note 92, Section 4.1.B. The criminal law is manifestation of the "legal-social control"; it has to be adopted by the elected body representing the public in order to reflect the "social consensus". The executive is not an elected body and cannot represent the social realities of the union. Hallevy, supra note 5, at 35, 36. Thus, the administrative agencies power is limited to making administrative offences which are punishable by moderate fine. Id., at 37

${ }^{103}$ For instance, see the Banking Business Proclamation No 952/2008, Art 58(7), Federal Government of Ethiopia Financial Administration Proclamation No 648/2009, Art 70(3). 
proclamations, ${ }^{104}$ and in other instances, general penalty clause is included. ${ }^{105}$ These state of affairs are contrary to the provisions and the spirit of the Criminal Code as enunciated under Art $3 .^{106}$

The legitimacy of such declaration was tested before the Federal Supreme Court in Daniel. ${ }^{107}$ In this case, the respondent was charged for violation of Directive CTG/001/97, issued by the National Bank of Ethiopia, by attempting to smuggle 46.96 kilos of gold to Djibouti. The Federal First Instance Court convicted and sentenced him to a term of imprisonment and fine as provided for under The Monetary and Banking Proclamation No 83/1994 Art 59(2)(b). ${ }^{108}$

The Federal High Court reversed both the conviction and the sentence. The ground for such reversal was that, the prohibited act was provided for in a Directive issued by the National Bank of Ethiopia. This Directive was not published in the official Negarit Gazeta and it was written only in English, which is not the working language in Ethiopia. The reversal was affirmed by the Federal Supreme Court.

However, the Federal Supreme Court Cassation Bench reversed the decision of the High Court and the Supreme Court and affirmed the decision of the First Instance Court. The Cassation Bench reasoned that the prohibited acts are provided for in the Directive. This Directive was adopted by the National Bank as authorised by the Proclamation. There is no law that requires the publication of Directives in the Negarit Gazeta, but this does not deny the Directive its quality as law. The Directive has to be interpreted in order to enforce the objective of the enabling Proclamation. Once the requirements of prohibition are established in the Directive, the punishments are to be determined according to the Proclamation, Art 59(2)(b).

This Cassation Bench binding interpretative decision itself understands its own predicaments; while there are countless directives issued by administrative

104 For instance, the Ethiopian Federal Government Procurement and Property Administration Proclamation No 649/2009, Art 77, the Trade Practice and Consumers' Protection Proclamation No 685/2010, Art 49, and the Banking Business Proclamation No $952 / 2008$, Art 58 provide for specific penalty for conducts contrary to respective proclamations.

105 The Transport Proclamation No 468/2005, Art 29, and Rural Land Administration and Use Proclamation No 456/2005, Art 19 made violation of the provisions of the Proclamations a criminal conduct punishable according to the Criminal Code.

${ }^{106}$ See Simeneh and Cherinet, supra note 92, Section 3.

${ }^{107}$ Ethiopian Revenue and Customs Authority v Daniel Mekonnen (Cass. File No 43781, 21 July 2010, Vol No 10).

${ }^{108}$ This proclamation establishes the National Bank of Ethiopia and defines its power until it was replaced with the National Bank of Ethiopia Establishment (as amended) Proclamation No 591/2008. 
agencies, it acknowledges that there is no law governing the publication or otherwise of such directives. The Cassation Bench further held, the decisions of the Federal High and Supreme Courts' were inconsiderate to such realities and such trend would render those several directives null. Such application of those rules as if they are 'legitimate' (while they are not truly legitimate for various reasons, such as, unconstitutionality) is pure "legalism" considering the law as "something given". ${ }^{109}$ If the rules are not published in the Negarit Gazeta, the court is not required to judicially notice, nor is a defendant denied of the right to defence of ignorance of law. ${ }^{110}$ In a criminal justice system severely wounded by over-criminalisation, this crippled application of the principle of legality only aggravates the problem.

\section{B. Application of the criminal law in terms of time}

An essential part of notice is the prospective application of the criminal law; the criminal law is applied prospectively. The retroactive application of the criminal law is limited to where such application would benefit the accused or the convicted person. Closely tied with the principle of legality and an overlapping principle given a constitutional norm status is the non-retroactive application of the criminal law. ${ }^{11}$ There is also another overlapping principle of the criminal law here -the principle of lenity- that every doubt favours the accused is applicable to such individual. ${ }^{112}$ It is stated that the criminal norms, the rules, are stated in the abstract, having no specific person or group in mind. Stated otherwise, the lawmaker cannot make laws having specific individuals or groups in mind because it is discriminatory; likewise, the lawmaker cannot circumvent the favourable application of the criminal law based on principle of lenity. ${ }^{113}$ However, there are tendencies of this sort as reflected in the customs proclamation, ${ }^{114}$ and the new corruption crimes proclamation. ${ }^{115}$

${ }^{109}$ Wintegen, at 25. Thomas refers to this formalism as "Muddling Along." E.W. Thomas (2005) The Judicial Process: Realism, Pragmatism, Practical Reasoning and Principles (Cambridge: Cambridge University Press), at $24 \mathrm{ff}$.

${ }^{110}$ Proc. No 3/1995, supra note 97, Art 2(2) and (3). Crim. C., Art 81.

${ }^{111}$ FDRE Const., Art 22.

112 Ibid. Crim. C. Art 5.

${ }^{113}$ Included in the generality of the statement of the law is equality before the law.

${ }^{114}$ The previous Customs Proclamation No 622/2009 is substituted by the recently adopted Customs Proclamation No 859/2014. The new proclamation decriminalises certain acts or reduces their punishment. However, Art 182of this proclamation provides that the cases that are pending are to be disposed of in accordance with the provision of the repealed Proclamation. However, this transitory provision should not be understood to have precluded the application of the provisions of the new Customs Proclamation to the extent it benefits the accused or the convicted person. FDRE Const., Art 22(2).

115 The Crimes of Corruption Proclamation No 881/2015 is adopted substituting those provisions contained in the Criminal Code. Art 37 this Proclamation provides that 


\section{Application of as to place}

The third sub-principle of the principle of legality relates to the application of the criminal law regarding place. It suffices to state here that such sub-principle is regarding the territorial applicability of the criminal law and jurisdiction. (See Crim. C., Arts 11-20).

\section{Interpretation}

The central issue of this article is interpretation of the criminal law. Although it is an important part of the subject under discussion, this sub-principle deals exclusively with strict interpretation of the criminal law. The positive nature of the criminal law requires the lawmaker to make the statements of the law to be clear so that the ordinary person would easily understand the law and be able to comply with the rules of conduct. ${ }^{116}$ This further requires the strict interpretation of the criminal law. It thus follows that while the principle of legality expressly authorises the interpretation of the criminal law, it precludes a specific type of interpretation -analogy- either in creating an offence or determining a measure or punishment. ${ }^{117}$

\section{E. Prohibition of Double Jeopardy}

The last element of the principle of legality provided for under Art 2(5) of the Criminal Code is the prohibition of double jeopardy. This is also a constitutional principle provided for under Art 23 of The FDRE Constitution. Thus, if a person, by a final judgment of a court, is acquitted or convicted of a crime, he may not be charged, nor tried for the same offence. ${ }^{118}$ The principle of legality has different content in different jurisdictions; formally, this last element of the principle of legality is unique to the Ethiopian criminal law. ${ }^{19}$

pending cases are to be completed in accordance with the provisions of the Criminal Code. However, if there are provisions that benefit the accused, the provisions of this Proclamation would be applicable despite such transitory provision.

116 In Europe, a "norm cannot be even be regarded as "law" unless it is formulated with sufficient precision" Ornowska, supra n 37, at 253.In the American system, it may be declared "void for vagueness." Ibid. Hallevy, supra note 5, at 13.

${ }^{117}$ Crim. C., Art 2(4). WorkuFekadu and ShumeArrarso v. BenishangulGumuz State Prosecutor (24 January 2013; Cass. File No 75387, Vol. 14).Freund, supra note 12, at 230.

118 This is also a ground of objection to the charge that precludes the court from looking into the merit of the case. Crim. Pro. C., Art 130(2)(b).

${ }^{119}$ For instance, the German principle of legality contains, among others, the principle of ultima ratio which is included under Art 1 of the Ethiopian Criminal Code. The English common law principle of legality, as part of the notion of rule of law, includes presumption of innocence. Hallevy, supra note 5, at 12, 13. However, as the prohibition of double jeopardy is recognized almost in every legal system, such uniqueness is not substantive. 


\subsubsection{Non-retroactive application of the law}

Another doctrine of the criminal law -which is also the other aspect of the principle of legality- is the non-retroactive application of the criminal law. ${ }^{120}$ Positively stated, this principle declares that the criminal law is applicable only after it is officially declared and cannot govern facts that occur prior to the coming into force of the law. ${ }^{121}$ This doctrine gives the impression that it is about the administration of the criminal law rather than interpretation of it. If we look at the prospective application of the criminal law, this doctrine is as much a rule of interpretation because it precludes the retrospective application of the criminal law. ${ }^{122}$

\subsubsection{The law that favours the accused shall be applied}

It is almost a universal principle that when there are two or more laws that are applicable on the same subject matter, the one that favours the accused is applied to the case. Such is the case where there are two or more provisions that are applicable to the same subject matter either at the same time or temporally different. ${ }^{123}$ There are several provisions that are redundant in the area of, for instance, tax law, license related crimes, crimes of corruption and terrorism. It is also a consistent practice in drafting administrative penal provisions that the lawmaker prefers severe penalty to mild ones. ${ }^{124} \mathrm{We}$ often see that courts follow this approach of the lawmaker -enforcing the severe penalty- rather than resorting to the milder ones, particularly in tax and license matters. Even though this drafting approach of the lawmaker is contrary to this principle, the court should always apply the law that favours the accused. ${ }^{125}$

\subsubsection{The rule of lenity}

This principle holds that the criminal law cannot be expanded beyond its scope and that every doubt favours the accused. ${ }^{126}$ This is reasonable when seen in

${ }^{120}$ Despite the fact that we have this doctrine in the 1957 Penal Code, Art 2, the Special Penal Code Proclamation No 8 of 1974was made applicable retroactively.

${ }^{121}$ This criminal law doctrine is also incorporated in the Constitution and is a constitutional principle, FDRE Const., Art 22. The distinction between two is that, the non-retroactive application of the law as incorporated in the Criminal Code is certainly a postulate as it is about the interpretation and application of the criminal norm. The prohibition of the retroactive application of the criminal law as incorporated in the constitution appears to be a principle because it provided for as an individual fundamental right it has direct application rather than about interpretation of the criminal law.

122 Ornowska, supra note 37, at 253, 254.

123 This is different from what is provided for under of the Crim. C., Art 6, which is an exception to the non-retroactive application of the criminal law.

${ }^{124}$ Simeneh and Cherinet, supra note 92, Section 4.3.A.

${ }^{125}$ Hallevy, supra note 5, at 144.

${ }^{126}$ Ornowska, supra note 37 , at 254. 
light of the principle of strict interpretation of the criminal law. ${ }^{127}$ This principle extending beyond the scope of the criminal law appears to have entered into the realm of evidence law. Thus, when the court is in doubt as to the application of the rule, it should decide such rule is not applicable. Likewise, where the court is in doubt as to the occurrence or existence of a fact, the court should also decide in favour of the accused.

\section{Object of Interpretation}

The doctrines discussed above guide how the court should interpret the criminal law; closely connected to this concept and practice of interpretation is the object of interpretation. There are different ways of putting criminal norms in hierarchy. For instance, Hallevy puts the criminal norms in four levels, supraprinciples at the top, followed by fundamental principles, secondary principles and specific legal provisions. ${ }^{128}$ Avila, on the other hand, does not put things in clear hierarchy but it appears he has some structure, super-principles at the top followed by principles and rules in their order. ${ }^{129}$ Summers, in his discussion on the theory of form of a legal system, has a structure of his own -general orders, maxims, principles and rules. ${ }^{130}$ Although their discussions are on different issues, they all focus on public law identified as an object of interpretation.

There is a general understanding that, it is the rules and principles that constitute the criminal norms as a result of which are subject to interpretation. ${ }^{131}$ However, another aspect of the object of interpretation is about the source of the material for interpretation. Discussing the source of the law, it is both formal and material. The formal source of the law, as discussed in relation to the principle of legality, is the lawmaker. However, irrespective of whether the source defines the scope of interpretation, there can be cogent arguments both ways. Therefore, it is unreasonable to exclude the subject of formal source from the object of interpretation, because the consequence of the interpretation may be that the law is not applicable to the facts of the case at hand, as in the case of Daniel. $^{132}$

The object of interpretation discussed here as the material source of the law is, such as, the text of the statute. As indicated earlier, it is rules and principles that are subject to interpretation and the meta-norms are about interpretation.

${ }^{127}$ Even though it is not separately discussed here, the principle of strict interpretation of the criminal law is an important principle which also forms a part of the principle of legality. Ornowska, supra note 37, at 257.

${ }^{128}$ Hallevy, supra note 5 , at 3.

${ }^{129}$ Avila, supra note 60, at 3.

${ }^{130}$ Summers, supra note 3, at 136.

${ }_{131}$ Avila, supra note 60 , at 83, 84.

${ }^{132}$ Daniel, supra note 107. 
Therefore, the material source of such rules and principles is the object of interpretation. This proposition does not end the argument at all. The principle of legality provides that there is no crime or punishment unless it is provided for in the law; and the law has to be clear. There is no crime by analogy and the criminal law is void when it is vague. Under such circumstances, the rules appear to command the exegetic approach that we cannot go beyond the text of the law.

As the criminal law is "text-oriented", to the extent we intend to apply the rules, the court should stick to the text of the statute. ${ }^{133}$ However, as the methods and manners of interpretation are inspired not only by criminal law theories, but also by constitutional and political thoughts, not all of them are written. ${ }^{134}$ To that extent, therefore, the court may go beyond the text. Hermeneutics argue that the interpretation of the law presupposes both context and prior knowledge of the meaning of words. ${ }^{135}$ Thus, we often go beyond the text seeking the help of "general principles of law". ${ }^{136}$ The hermeneutic thesis challenges the exegetic approach taking statute as the only source of law and interpretation is only searching for the intention of the lawmaker. ${ }^{137}$ The hermeneutic approach helps both to understand the law and to justify the use of general principles of law in the interpretation and application of the criminal norms. ${ }^{138}$

In this case, one may have reservation on the application of the general principles of law in the face of the argument for strict interpretation of the criminal law and nullity for vagueness. However, hermeneutic approach only puts the things we know in context that are unavoidable human aspects -our idiosyncrasies, bias and prejudice, the pragmatic use of language in a particular social and historical context. ${ }^{139}$ Even though the nature of the criminal law is "text-oriented", "textuality" of the interpretation of the criminal law is too simplistic that it only solves minor problems that could be addressed by

${ }^{133}$ Ornowska, supra note 37 , at 271.

134 Id., at 254.However, the obvious hermeneutic interpretation comes from a different source, such as, the constitutional law and human rights law unless we attempt to extend the principle of coherence to integrate the criminal law to other branches of law that have direct impact. Id., at 258.

135 Hermeneutic approach involves interpretation and understanding of the law at three levels: (a) reaction to the meaning of the law; (b) explication of the law; and (c) application of the legal standards to the facts of a case. Ornowska, supra n 37, at 260.

${ }^{136}$ M. van Hoecke (2002) Law as Communication (Oxford: Hart Publishing), at 116, 161 165.

${ }^{137}$ Ibid. Bonnecase, supra note 31 , at 87,88 .

${ }^{138}$ van Hoecke, supra note 136, at 165.

${ }^{139}$ Ornowska, supra note 37 , at 263. 
semantic interpretation. Thus, strict interpretation of the law does not give accurate depiction of the reality. ${ }^{140}$

\section{The Criminal Norm that Needs Interpretation, and the Effect of Such Interpretation}

Often, it is believed interpretation of the law is sought when the law is vague, or if there is a contradiction within the law or between the different legislation, or between one branch of law and another, such as, between the criminal law and the Constitution. Moreover, interpretation becomes necessary when there is a gap in the law, or the law is ambiguous or equivocal, or the literal meaning of the law appears 'absurd' or at variance from the intention of the lawmaker. Stated otherwise, when the law appears to be clear, it is believed that it needs no interpretation $^{141}$ because interpretation is believed to remedy those deficiencies in the law -resolving conflict, clarifying ambiguity or equivocation, addressing gaps or the variation of objective and subjective intention of the lawmaker.

However, when somebody proposes that the law is clear, such proposition is based on foreknowledge she thinks is shared. Otherwise, when somebody holds the law is clear it only means "it is less obscure"; ${ }^{142}$ even the assertion that the law is clear requires an extensive argument. ${ }^{143}$ If the proposition that interpretation is finding the facts of the case and finding the law that is applicable to the facts of such case is palatable, then interpretation is ever present in the judicial decision-making process. Even when the law appears to be clear, the court uses literal interpretation and the systematic interpretation. In fact, if interpretation is a dialogue between the text of the law and the judge, and this is done through reading of text of the law, the judge is never an "inert" reader. ${ }^{144}$

The various doctrines of the criminal law are used in 'scaffolding' the scope and content of the criminal law thereby guiding the interpretation of the criminal law. ${ }^{145}$ Interpretation is the bridge between the text of the law and the fact situation in real life. It is through interpretation and application that the criminal law is 'transformed' into reality ${ }^{146}$ and enters into the social consciousness. ${ }^{147}$

\footnotetext{
${ }^{140}$ Id., at 272.

${ }^{141}$ Freund, supra note 12 , at 218 . Wintgens, supra note 4 , at 18.

${ }^{142}$ Halperin, supra note 10, at 37. Ornowska, supra note 37, at 268.

${ }^{143}$ Silving, supra note 36 , at 520, 521.

${ }^{144}$ Ornowska, supra note 37 , at 263.

${ }^{145}$ Avila, supra note 60, at $92 \mathrm{ff}$.

${ }^{146}$ Zamboni discusses statute as "not-yet-law" which is transformed into "already law" by the process of interpretation. For him, interpretation transforms the "text" of the law into "law". Zamboni, supra note 4.

${ }^{147}$ Mohnhaupt, supra note 13, at 61. Landecker, supra note 58, at 553.
} 
The effect of interpretation may be deciding the law inapplicable or void. In the course of interpretation, the court disregards a legal provision if it determines that a certain provision of the criminal law is vague or has gaps that cannot be filled in by the application of the general principles of the criminal law or the rules are contrary to the basic doctrines of the criminal law. Where the law is applicable to the facts of the case, the court applies the law that is most suitable to the facts having regard to all the relevant factors. ${ }^{148}$

\section{The Interpretative Power of the Courts and the Cassation Bench}

Interpretation is constitutionally recognised ${ }^{149}$ fundamental judicial power and the court has monopoly of truth. ${ }^{150}$ The interpretative power of the court includes the determination of the interpretative question, the desirable method and manner of interpretation, the applicable law and the facts that are proved. The FDRE Constitution not only establishes the courts, it also vests the interpretative power in the courts exclusively. ${ }^{151}$ The Constitution further recognises the power of the Federal Supreme Court to review cases in cassation on matters that contain fundamental error of law. ${ }^{152}$ This power of the Federal Supreme Court Cassation Bench is further expanded by the Courts ReAmendment Proclamation No 454/2005, Art 2 that renders the interpretative decision of the Cassation Bench (by at least five judges presiding), binding on lower courts.

The issue of "binding interpretative decision" needs serious consideration in criminal law. Although the concept of "binding interpretative decision" is not defined in the Proclamation, it means the lower courts are bound by the manner of interpretation of the law by the Cassation Division on similar matters. The raison d'être for adopting such a practice is the creation of consistency and uniformity in the interpretation and application of the law. It is stated earlier that

${ }^{148}$ In this regard, hermeneutic approach requires the contextual understanding of the law in historical context. It is an author-oriented interpretation. This helps the proper understanding of the law and enables comprehending the problem the law is intended to resolve. Ornowska, supra note 37, at 260.

${ }^{149}$ FDRE Const., Art 78(1); 79(1)-(3). Ornowska, supra note 37, at 257, 269

${ }^{150}$ See supra $n$ 62, 63. By monopoly of truth, it means, the court that decides whether a particular fact is proved or not. Ornowska, supra note 37, at 269, 270. Morigiwa, supra note 13 , at 126 ,

${ }^{151}$ FDRE Const., Art 78(4). The Constitution also prohibits the establishment of special courts.

${ }^{152}$ Id., Art 80(3)(a). 
interpretation, in general gives legitimacy and stability to the law because it is an act of affirming the law not changing the law. ${ }^{153}$

It is evident from the reading of the provisions of Art 2 (of Proc No 454/2005) that the interpretative power of the Cassation Bench is limited to such act as constituting and giving effect to the law and not changing or deviating from the law. If the interpretative act of the Cassation Division does not appear different from the power of other courts but the former's decision is binding on the lower courts in similar matters, the question then is what is the scope of interpretative power of the Cassation Court? This question may be seen in light of the basic doctrines of the criminal law, such as, the principle of legality, strict construction of the criminal law, prohibition of interpretation of the criminal law by analogy, the principle of "void for vagueness", etc. because these doctrines are binding on any court, including the Cassation Division.

We can put the decisions the Cassation Court rendered on criminal matters under different categories. The first category includes cases, such as, Worku and Shume ${ }^{154}$ and Jemila, et. al. ${ }^{155}$ in which the court enunciated the principle of legality and the principle of conduct; in Solomon, ${ }^{156} \mathrm{Habtu}^{157}{ }^{157}$ and Felekech ${ }^{158}$ the Court interpreted the principle that the law that is favourable to the accused is applicable. Each of those binding interpretative decisions is reasonable interpretation of the criminal law as they were made by merely finding the law applicable to the facts of such cases. Those interpretations made on the criminal law could have been made by any court and there is no prohibition to such interpretation, nor does such interpretation require special authorisation. This category of interpretation is not particular to the Cassation Bench because its binding nature emanates from the law, and the concept of binding interpretative decision in the criminal law merely reiterates the principle that is envisaged in criminal law.

The second category of decisions would include giving effect to legislations that apparently lack the essential qualities of the criminal law. Such is case with Daniel $^{159}$ where the defendant was charged and convicted as though he violated

${ }^{153}$ Zimmermann, supra note 13 , at 318.

${ }^{154}$ Workuand Shume, supra note 117.

155 Jemila Mohammed Hagos, et. al. v. Federal Public Prosecutor (26 February 2009, Cass. File No 38161, Vol. 9).

${ }^{156}$ Solomon Desalegn v. Southern Regional State Prosecutor (15 May 2014, Cass. File No 95438, Vol. 16)

${ }^{157}$ Habtu Tulu v. Federal Ethics and Anti-Corruption Commission (22 June 2015, Cass. File No 103775, Vol. 18).

${ }^{158}$ FelekechHailegebriel v Oromiya Justice Bureau (6 August 2009, Cass. File No 44031, Vol 9).

${ }^{159}$ Daniel, supra note 107. 
a legislation adopted by the House of Peoples' Representatives for violating a directive issued by the National Bank of Ethiopia. As indicated in Section 3.3.2(A), this directive is written in English, and it is not published in the Negarit Gazeta.

The third category of decisions are related to legalism, i.e., the Cassation Court applied the formal laws that are contrary to the fundamental doctrines of the criminal law. Such is the case with, for instance, imputation of criminal responsibility. In Bereha and several other similar cases, ${ }^{160}$ the Cassation Court held that a manager may be criminally responsible if the company is held criminally responsible for tax offences. This makes the manager criminally responsible only for being a manager without there being an act or the required moral element on the part of the manager. For that matter, the act could possibly be committed by other employees of the company in the absence of the manager. This is contrary to the provisions of Articles 44 and 34 of the Criminal Code regarding the personal nature of criminal responsibility and corporate criminal responsibility, respectively. Even though the decisions of the Cassation Bench in this third category do not necessarily deviate from the wording of the law, they give effect to laws that are contrary to the basic doctrines of the criminal law which should have been made void.

The fourth category of decisions of the Cassation Bench may be those wherein the court deviates from the clear wording of the law; Sgt. Mekonnen and Hassan are cases on point. ${ }^{161}$ The provisions of Art 75 of the Criminal Procedure Code are clear that appeal from a bail decision may be lodged by a person who is denied bail. In these cases, the individuals were granted bail by

${ }^{160}$ Tigrai Revenue Development Authority v. Bereha Reda (01 October 2013, Cass. File No 86597, Vol. 15,).Ethiopian Revenue and Customs Authority v. AbkaleEndeshaw (29 October 2012, Cass. File No 74237, Vol. 14).The Twins Bar and Restaurant PLC and Tsige Wolde v. Ethiopian Revenue and Customs Authority (22 December 2010, Cass. File No 51090 Vol. 11).Tarekegn G/Giorgis, et. al., v. Ethiopian Revenue and Customs Authority (17 December 2009, Cass. File No 48850, Vol. 10). Ouqubay Bereha v. Ethiopian Revenue and Customs Authority (13 March 2015, Cass. File No 100079, Vol. 17).

161 The Cassation Bench gave a binding interpretative decision on Crim. Pro. C., Art 75 in Amhara Regional State Justice Bureau v. Sgt. Mekonnen Negash (2008 Cass. File No. 35627). Despite the decision was not published in the Supreme Court case reports courts were routinely following it. The same interpretative decision was rendered in Hassan Abdella v. Federal Public Prosecutor (2 November 2015, Cass. File No 112725, Vol 19). It is worth noting that the Revised Anti-Corruption Special Procedure and Rules of Evidence Proclamation No 434/2005, Art 4 provides for release on bail and Art 5 provides for appeal from a decision on bail matter which is available both to the accused and the investigator or the public prosecutor. However, the application of this provision was limited to individuals suspected of crime of corruption that it cannot be extended to other forms of crimes. 
the lower courts and prosecution appeal was lodged to the appellate court where they were denied bail. In Mekonnen, the Amhara Regional Supreme Court Cassation Bench decided, Art 75 does not grant the right to appeal (against bail) to the Public Prosecutor. Petitions against the grant of bail were filed before the Federal Supreme Court Cassation Division which rendered a binding interpretative decision on Art 75 stating that the provision does not deny the Public Prosecutor to lodge an appeal from a decision granting bail to a suspect. This is not only contrary to the doctrines of the criminal law, but goes beyond the scope its power to give a binding interpretative decision that is clearly stated under the Proclamation that states the power of the Cassation Bench. ${ }^{162}$

It is to be noted that the Federal Supreme Court Cassation Bench is not empowered to affect the content and scope of the criminal law as proclaimed by the lawmaker. Its power is limited to making correct decisions (publishing those decisions and distributing them). This can serve the purpose of enhanced consistency in court decisions rather that the broadening of the Cassation Bench's scope of authority in interpretation.

\section{How Interpretation of Criminal Norms is Conducted?}

\subsection{Ordinary Methods of Interpretation}

As alluded to earlier, the outcome in interpretation is often determined by the process -how the provision is interpreted- and not necessarily by the content of the provision. The meta-norms guide the interpreter in the interpretation process, the actual methods of interpretation are discussed in this section, including how interpretation should be conducted. Both the problems of rule formalism as well as process formalism are discussed in this section. Formalist judges influence the outcome of the case making justice a mechanical process. Thus, in as much the method of interpretation matters, how the institutions of interpretation engage in the process understand their role matters, if not more. ${ }^{163}$

162 The Cassation Bench over stretched its "power" that in a binding interpretative decision it gave effect to a repealed law in Customs Prosecutor v BantiTa'era (25 March 2008, Cass. File No 28952, Vol 7). The issue was whether the public prosecutor can reinitiate a charge which it withdrew by virtue of Crim. Pro. C., Art 122(2). The Cassation Bench held that a charge withdrawn by virtue of Art 122(2) may be reinstituted by virtue of Art 122(5). However, the provisions of Art 122(2) were specifically repealed by Office of the Central Attorney General of the Transitional Government of Ethiopia Establishment Proclamation No. 39/1993.

163 Thomas, supra note 109, at 7-14. 


\subsubsection{Literal interpretation}

Legislative rules are expressed in words and the legislature is presumed to have chosen those words carefully to have legal effect. ${ }^{164}$ The criminal norms must be clear and intelligible to the ordinary person so that she could conform her conduct to the requirements of the law. It is now presumably a universal rule that the criminal law is interpreted strictly. ${ }^{165}$ Of all the methods of interpretation that are applicable in continental Europe, the literal or grammatical interpretation is employed whenever the words of the rules are clear complemented by systematic interpretation. ${ }^{166}$

The criminal law doctrines manifest commitment to the literal interpretation of the criminal norms. ${ }^{167}$ Where there is a variance between the intention as expressed in the law (objective intention) and the presumed (subjective) intention, in the criminal law area, it is the objective intention to which the court gives effect. ${ }^{168}$ Such variance has different effect based on the nature of the law; in criminal law, guided by the principle of lenity, such variation may be given effect depending on whether it is to the benefit of the accused.

\subsubsection{Logical interpretation}

Logical reasoning is said to be "the only respectable method of reasoning" in continental Europe. ${ }^{169}$ Logical interpretation may be seen in two ways. The most common one is syllogism - the law is the major premise; the facts of the case are the minor premise and the judgement is a conclusion. ${ }^{170}$ Legal syllogism applies at the stage of application of the criminal law to the facts of a case. However, there are diverse logical interpretations both for the purpose of finding the law, for the facts of the case and giving content to the words of the law, such as, contextual reading which requires deduction or induction.

\footnotetext{
${ }^{164}$ Freund, supra note 12 , at 218

${ }^{165}$ Id., at $213,214,217$.

166 V. Sacks and C. Harlow (1977) "Interpretation, European-Style" In 40 The Modern L. Rev., No 5, at 579

${ }^{167}$ Ornowska, supra note 37, at 252, 253.

${ }^{168}$ In Germany, the objective meaning is advocated because as it is drafted by professionals "the statute may be more intelligent than the legislator" Silving, supra note 36, at 507, 508, note 33. In France, it is called "presumed intention." Bonnecase, supra note 31, at 87. This is what Ornowska referred to as "the canon of text objectivity" because preference is given to the objective intention of the lawmaker through interpretation. Ornowska, supra note 37, at 262, 263.

169 Prott, supra note 58, at 428. Even in the common-law system, legal reasoning follows a certain pattern: Issue, Rule, Application and Conclusion. Leaving aside the issue, which is permeating every litigation, the rest of the structure of the argument constitutes a syllogism.

${ }^{170}$ Id., at 420 .
} 


\subsubsection{Systematic interpretation}

Codes are different from statutes in that their formulation (in terms of structure and in terms of the statement they use) has the highest level of abstraction. ${ }^{171}$ This is based on the fact that a code is a comprehensive and harmonised body of law on a particular area. However, there is no different method of interpretation of codes and statutes. ${ }^{172}$ This is particularly so in criminal law where the interpretation of statutes is guided by the General Part of the Criminal Code.

The Criminal Code is supposed to be the sole or the principal source of the criminal norm. ${ }^{173}$ Administrative legislations would only contain administrative sanctions by administrative agencies or fine. ${ }^{174}$ Any special penal legislation must mean to govern extra-ordinary situations that were not foreseen by the Criminal Code and which cannot be reasonably accommodated in the Criminal Code. However poorly organised they may be, the Criminal Code, special penal legislation, and administrative regulations containing penal provisions constitute one body of law -the criminal law. In order to find the law and apply to the specific facts, the system of the organisation should be taken into consideration.

\section{A. The General Part $v$ the Special Part of the Criminal Code}

The criminal law has both a rule of conduct and a rule of adjudication aspect. Thus, the General Part is the one that is most essential for adjudication than for notice. ${ }^{175}$ The rules of adjudication appear to be more complicated and substantial in number than the rules of conduct. ${ }^{176}$

It is the General Part that defines not only what a punishable conduct is but also what the lawmaker can criminally punish. ${ }^{177}$ As seen in the interpretation of the Criminal Code, in the tripartite interpretation, the objective elements, the subjective elements, responsibility, justifications, excuses, and related matters are provided for in the General Part of the Criminal Code. ${ }^{178}$ The general framework of the criminal law is laid down in the General Part of the Criminal

${ }^{171}$ Graven, supra note 39, at 282, 287. B.W. Frier (1991) "Interpreting Codes" 89 Michigan L. Rev., No 8, at 2205.

${ }^{172}$ Id., at 2209.

${ }^{173}$ Graven, supra note 39, at 282, 284, 287. Simeneh and Cherinet, supra note 92, Section 3.

${ }^{174}$ See the discussion made regarding the content of Art 3 of the Criminal Code in Simeneh and Cherinet, supra note, Section 3.

${ }^{175}$ This is what Robinson refers to as ex-post function of the criminal law. Robinson, supra note 42 , at 5,7 .

${ }^{176} \mathrm{Id}$., at 7. In this context, the rules of adjudication include not only the General Part of the Criminal Code but also the provisions of the Criminal Procedure Code, and the Constitution.

177 Simeneh and Cherinet, supra note 92, Sections 2.2. and 2.3.

178 Robinson, supra note 42, at 5. 
Code. Thus, the General Part of the Criminal Code contains substantial size of doctrines that shade light on the Special Part of the Code.

All the doctrines discussed here, such as, principle of legality, nonretroactive application of the criminal law and the principle of lenity, are found in the General Part of the Criminal Code. Further, the General Part addresses specific issues. For instance, if the moral element is not provided for in the Special Part of the Criminal Code, it is provided that the moral element required for such conduct is intention. ${ }^{179}$ The Special Part of the Criminal Code provides for specific acts that are criminalised and the consequent measures when such provision is violated. As such, the Special Part is given effect only when seen through the lens of the General Part. Therefore, the systematic reading and understanding of the Code or the criminal law in general is necessary both for the purpose of finding the law as well as for the proper application of the law

B. The General Part of the Criminal Code v special penal legislation and administrative regulations containing penal provisions

Art 3 of the Criminal Code provides for the possibility of having a special legislation of penal nature. Certainly, there are several special penal legislation and administrative legislation containing penal provisions. ${ }^{180}$ The Criminal Code is explicit in stating that the General Part of the Criminal Code is applicable to those other legislation, unless the latter expressly sets aside the application of the General Part to such legislation. So far, there is no such legislation which excludes the application of the General Part of the Criminal Code. ${ }^{181}$ Therefore, the provisions of special penal legislations and the penal provisions of administrative legislation may be interpreted in conformity with the principles of the General Part of the Criminal Code.

\section{Purposive interpretation of the criminal law}

This method of interpretation is evident from the discussion on the doctrine of the common good. It is further stated earlier that the purpose of the criminal law is prevention of crime by giving due notice and when it is not complied with it provides for specific measure or punishment. The punishment is imposed not for any particular reason but to show to the public that the promise is genuine. ${ }^{182}$

\footnotetext{
${ }^{179}$ Crim. C., Arts 58(3), 59(2).

${ }^{180}$ The nature of those special penal provisions is discussed in Simeneh and Cherinet, supra note 92 , Section 3.

${ }^{181}$ Ibid.

${ }^{182}$ Landecker, supra note 58, at 554. C. Beccaria (1995) Beccaria On Crimes and Punishments and Other Writings, R. Bellamy (Ed.) (Cambridge: Cambridge University Press), at 31. E. Monachesi (1955) "Pioneers in Criminology: IX Cesare Beccaria (17381794)" In 46 J. of Crim. L., Criminology and Police Science No 4, at 455.
} 
This purpose governs the whole of the criminal law. ${ }^{183}$ Penal provisions contained in administrative legislation and special penal legislation have an identical purpose that is provided for under Art 1 of the Criminal Code, which affects the legitimacy of such rules. ${ }^{184}$ Therefore, when any criminal norm is interpreted, it must be interpreted in light of its purpose as stated under Art $1 .{ }^{185}$

\section{The tripartite interpretation of the Criminal Code}

The Ethiopian Criminal Code is a continental code both in content and structure. The Code fully integrates the theories of crime and punishment developed in the continental legal culture into its corpus. ${ }^{186}$ As such, it also takes after the continental tradition in the interpretation and application of the criminal law.

The continental criminal law adopts a tripartite interpretation method. ${ }^{187}$ First the court establishes whether both the material and the subjective elements of the crime are present within the meaning of Art 23 of the Criminal Code. Once the court establishes the existence of both the moral and material elements of the crime, it then goes to the determination of the existence of justificatory defences negating criminal responsibility. ${ }^{188}$ For instance, Arts 78 and 75 respectively deal with legitimate defence, and necessity. Finally, where there is no justification, the court determines the existence and extent of excusable defences. Excusable conduct does not negate criminal responsibility but it only reduces the criminal responsibility of the accused.

\subsection{Against Interpretative Formalism}

Methods and rules of interpretation constitute the skeleton of the interpretative process of criminal law; the response to the question 'how to interpret?' is the blood and flesh. Interpretation is always skewed by the view of the interpreter about the law and the judicial process. When the court interprets the law, it should "tend to be public reasoned and justice oriented" ${ }^{189}$ It is public reasoned

183 Graven, supra note 39, at 282.

${ }^{184}$ It is this method of looking at the Directives adopted by the National Bank of Ethiopia that the Federal Supreme Court missed in Daniel, supra note 107.

${ }^{185}$ Hallevy, supra note, at 144

${ }^{186}$ See Simeneh and Cherinet, supra note, Section 2.8.

187 This is initially developed in the German criminal law but it is also borrowed and transplanted to all other continental criminal law system. See Dubber, supra note 92, at 681; T. Vormbaum and M. Bohlander (Eds.) (2014) A Modern History of German Criminal Law (Berlin: Springer), at 16, 17. A. Petrig and N. Zurkinden (2015) Swiss Criminal Law (Zurich: Die Deutsche Bibliothek), at 56, 91, 98.

${ }^{188}$ Persak states that the court is evaluating the wrongfulness of the conduct itself. This contradicts with her statement that criminalisation is a matter of policy decision not based on the inherent quality of the conduct itself. Persak, supra note 92, at 5, 108-110.

${ }^{189}$ Morigiwa, supra note 13 , at 136. 
because justice is "a public good like clean air, water and roads" and it is rendered in society.

Interpretation should also strive to achieve justice. ${ }^{190}$ Lawmaking is "value creation [...] informed by theories of justice and fairness" and when the law fails to achieve that, the courts are there "to ensure rationality and justice in the law" through interpretation. ${ }^{191}$ There are those who consider judicial interpretation as a process and there are those who believe the court should be progressive to meet the demands of the day. There are also pragmatists who balance both the form and the substance of the law. ${ }^{192}$

Positive law is prone to be formalist, and formalism is "a clear opponent of fairness and justice" as it masks the choices, and it renders judicial reasoning a mechanical and "artificial process." 193 A formalist judge believes he is sticking to the 'rules' of the law, it is a preference the judge makes disregarding several choices which are not made clear in the judgment. ${ }^{194}$ Despite the growing disfavour to formalism, ${ }^{195}$ there are factors that limit the judge's independence, forcing him to be formalist. They are put under three broad categories: external constraints, ${ }^{196}$ internalised constraint ${ }^{197}$ and structural constraints,

Under structural constraints, fall "a number of preconceptions, predilections and prejudices" that result from a formalistic approach. ${ }^{198}$ These are effectively reflected in treating certainty as a primary goal of adjudication as reflected in the sentencing guideline, overtly coercive and unwavering compliance with the binding interpretative decision of the Cassation Bench, ${ }^{199}$ leaving any significant

${ }^{190}$ Id., at 137.

${ }^{191}$ W.N. Eskridge, Jr. (2010) "Interpretation of Statutes" In D. Patterson (Ed.) A Companion to Philosophy of Law and Legal Theory, Second Ed. (West Sussex: Wiley-Blackwell), at 194.

${ }^{192}$ Id., at 195.

${ }^{193}$ Thomas, supra note 109 , at 55.

${ }^{194}$ Ibid.

${ }^{195}$ Formalism in the sense that is put by Thomas, supra note 109 , not in the sense that is put by Summers (supra note 3 ).

${ }^{196}$ Listed in this category are review of the decision of the judge by appeal, requiring the judge to give reason for a decision, her legal education and training, and community assessment keeps her accountable to a certain process. Thomas, supra note 109, at 24345.

${ }^{197}$ Included in this category are institutional commitments of the judge to the judiciary by oath of office and ethical rules of propriety and judicial self-restraint. Thomas, supra note 109 , at $246-47$

198 Thomas, supra note 109 , at 249

199 It is a routine practice regarding the interpretation and application of a particular provision that where there is a specific cassation decision and litigants cite such decisions, the court follows such interpretation of the Cassation Court scrupulously. 
changes to the lawmaker, ${ }^{200}$ consequently, showing preference to matters of form than to substance when the two show apparent conflict, in general maintaining minimum judicial discretionary power. ${ }^{201}$ Besides the self-imposed and other traditional restrictions on the court, the latter is further coerced by the lawmaker as evidenced by the Federal Supreme Court Sentencing Guidelines and the binding nature of the Cassation Court interpretative decisions. It may be argued that both the Sentencing Guidelines and the binding interpretative decisions of the Cassation Court are internalised constraints.

\subsubsection{The Federal Supreme Court Sentencing Guidelines}

The Criminal Code is comprehensive. It has the material and subjective requirements constituting a crime, participation in and responsibility for criminal conduct, justificatory and excusatory defences. Further, should defendant get convicted, the types of measures and punishments to be imposed are fixed in fairly proper order. ${ }^{202}$ The rules regarding the determination of sentence are also complete. The particular provision criminalising the particular conduct provides for a specific punishment. In the General Part, there are special and general aggravation (Arts 84, 85, 86) and mitigation grounds (Arts 82, 83, 86). The only gap we may find in the Criminal Code is how each aggravation or mitigation ground may be evaluated. ${ }^{203}$

Despite such a Criminal Code that has adequate clarity, the lawmaker authorises the Federal Supreme Court to adopt a sentencing guideline. ${ }^{204}$ The preamble of the initial Sentencing Guideline (No 1/2002) states the reasons for

${ }^{200}$ As seen in Daniel, supra n 107, the Supreme Court has shown high level of legalism not only by leaving things for the lawmaker but also applying whatever the lawmaker legislated on.

${ }^{201}$ Thomas, supra note 109 , at 249.

202 If at all there are reservations regarding the Criminal Code, it is not a matter of application; the Criminal Code is, unnecessarily, too comprehensive, and often the punishments are unreasonably high.

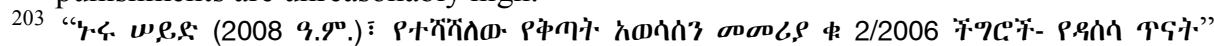
In 5 Ethiopian Bar Review No 1 (hereinafter "Nuru"), at 159.

${ }^{204}$ It is cogently argued by Nuru that the sentencing guideline is on matters that are well covered by the Criminal Code. Whether the House of Peoples' Representatives has the power to delegate such power to the Federal Supreme Court may be seen along with the criminal law-making power of the House under section 7.2.1., infra. Both Sentencing Guidelines begin by aggravating the sentences from that what is provided for in the Criminal Code, (Nuru, supra n 203, at 133) and in certain instances, they are arbitrary. For instance, each mitigation grounds in the first Sentencing Guideline would mitigate the sentence two steps; in this the second Sentencing Guideline, each mitigation ground reduces the sentence only by one step. (Nuru, at 139, 148, 149). There is no reason provided for by the Supreme Court why the effects of mitigation grounds are dramatically reduced, but it is binding on the courts anyway. 
adopting the guideline as the need for uniformity and predictability. ${ }^{205}$ In criminal law, the reason why the judge should interpret the law independent of other interferences is in order to empower him render justice.

In criminal law, prime focus is accorded to substantive justice rather than distributive justice. However, the sentencing manual, sticks to the similarity of punishment, i.e., the distributive justice. In a system of criminal law, which manifests the negative distribution of benefits as positive act of distribution of burdens, the substantive justice outweighs the distributive justice. Often it is argued that the central tenet of the criminal justice is whether a person is punished in proportion to his guilt. Therefore, it is material to see to it that the person gets the measure of punishment in proportion to his guilt than whether a defendant is sentenced to the same or similar measure or punishment another defendant in similar or identical position has undergone. No two cases could be identical. However, the sentencing guideline principally focuses on the uniformity of the sentence and the predictability of the sentence. It guides every judge and practitioner to arrive as a mathematically precise sentence for every case, ${ }^{206}$ this is quintessentially judicial formalism.

\subsubsection{The binding interpretative decisions of the Cassation Bench}

One of the attempts by the lawmaker to infuse and entrench formalism into our courts is the introduction of binding interpretative decisions of the Cassation Bench of the Federal Supreme Court. Art 2 of Proc No 454/2005 provides that a decision rendered by the Cassation Bench, where at least five judges are sitting, has a binding effect on every other court. ${ }^{207}$ The Federal Supreme Court is under a duty to publish and disseminate such decisions. It is not clear though whether

${ }^{205}$ In fact, the Sentencing Guideline describes the sentencing disparity in the sentencing practice prior to the adoption of the first Guideline in a denigrated manner that "no two criminal sentences are identical...if at all they are identical it is a mere accident." [translation mine]. Sentencing Guideline No 1, Preface, paras 1 and 2. The Preamble leaves no room for doubt that the judges do this by disregarding the law. There is no evidence provided for in the Sentencing Guideline, or in other researches for that matter, the judges of our courts consciously and deliberately ignored the law. The Guideline should not have made applying the law an issue; it should rather have made it the issue of "what is the law? and what is the effect of each aggravation of mitigation ground?"

206 The Federal Supreme Court Sentencing Guideline No 2, Art 27 provides that a judge who believes she has to deviate from what is provided for under the Guideline, she may do so by providing "detailed reason" and forwarding the decision to the Supreme Court, State or Federal, as the case may be. Obviously, it is easy for the judge to conform to the Sentencing Guideline than to give reason for deviation.

207 The Cassation Court is established to correct fundamental errors of law. This is a constitutional power which is binding only on the parties to that particular case decided before the Cassation Bench. What is provided for under Art 2 of Proc. No 454 is further power to bind all other courts by such decision. 
the decision of the court is binding as it is, or only if it is selected for publication and circulation. However, one of the elements of the principle of legality is publication of the criminal norms. In accordance with the principle of legality and the spirit of the provisions governing the subject as stated in the introductions to those case report publications, the binding interpretative effect of decisions of the Cassation Court should thus only apply to the ones that are published.

The purpose of the introduction of the binding nature of the Cassation Bench decision is clear -that it is meant to establish a uniform interpretation and application of the law. "Certainty and predictability are virtues;" however, it should not be "intuitively and blindingly treated as a goal of adjudication" and it should not override the interest of justice. ${ }^{208}$ As the application of the Federal Supreme Court Sentencing Guideline may be set aside by providing the reasons thereof, the application of a binding interpretative decision may be made inapplicable by distinguishing the facts, or providing reason, such as, such decision was made in excess of the power of the Cassation Court.

\section{Conclusion}

The contemporary description of a legal system is that it contains norms, institutions and methods, among others, interpretation being only one part of the latter. The norms are seen as institutions as they have both normative aspect as well as real effect in life. However, the effect of those norms is determined by the method and manner of interpretation adopted by the court. In order to help the interpretation and application of the norms in the Special Part of the Criminal Code and other penal legislation, the General Part contains metanorms, often called general principles.

The meta-norms do not solve the problem; the court needs to adopt a theory of its own regarding the nature of the law, and define its role in the administration of the criminal justice. In so doing, courts must uphold justice as their central responsibility. Thus, a court should strive to achieve substantive as well as procedural justice by letting itself off the shackles of formalism both self-imposed and imposed from the outside. It is not an easy task; nor is it unattainable. Courts can, for instance, set aside a binding interpretative decision of the Cassation Bench where they find that it negates justice or their conscience by properly distinguishing the facts; they can also declare a threshold stated in the Federal Supreme Court Sentencing Guideline inapplicable in the particular case where they find it gravely unjust, provided they give valid reasons that serve the law, truth, reason and justice.

${ }^{208}$ Thomas, supra note 109 , at 250 . 